\title{
Insulin Attenuates Agonist-mediated Calcium Mobilization in Cultured Rat Vascular Smooth Muscle Cells
}

Fumio Saito, Mark T. Hori, Marianne Fittingoff, Toru Hino, and Michael L. Tuck

Division of Endocrinology, Veterans Affairs Medical Center, Sepulveda, California 91343;

and UCLA School of Medicine, Los Angeles, California 90024

\begin{abstract}
Insulin has been shown to attenuate pressor-induced vascular contraction, but the mechanism for this vasodilatory action is unknown. This study examines the effect of insulin on angiotensin II (ANG II)-induced increments in cytosolic calcium in cultured rat vascular smooth muscle cells (VSMC). 20-min incubations with insulin $(10 \mu \mathrm{U} / \mathrm{ml}$ to $100 \mathrm{mU} / \mathrm{ml})$ did not alter basal intracellular calcium concentration $\left(\left[\mathrm{Ca}^{2+}\right]_{i}\right)$, but inhibited the response to $100 \mathrm{nM}$ ANG II in a dose-dependent manner (ANG II alone, $721 \pm 54$ vs. ANG II $+100 \mathrm{mU} / \mathrm{ml}$ insulin, 315 $\pm 35 \mathrm{nM}, P<0.01$ ). A similar effect of insulin on ANG II action was observed in calcium poor buffer. Moreover, insulin did not effect calcium influx. ANG II receptor density and affinity were not affected by $24-h$ incubation with insulin. To further clarify the mechanisms of these observations, we measured ANG II-induced production of inositol 1,4,5-triphosphate $\left(\mathrm{IP}_{3}\right)$, and $\mathrm{IP}_{\mathbf{3}}$-releasable ${ }^{45} \mathrm{Ca}$. Insulin treatment did not alter ANG II-stimulated IP $_{3}$ production. However, IP $_{\mathbf{3}}$-stimulated release of ${ }^{45} \mathrm{Ca}$ in digitonin permeabilized cells was significantly reduced after 5-min incubations with $100 \mathrm{mU} / \mathrm{ml}$ insulin. Thapsigargin induced release of calcium stores was also blocked by insulin. Thus, insulin attenuates ANG II-stimulated $\left[\mathrm{Ca}^{2+}\right]_{\mathbf{i}}$ primarily by altering $\mathrm{IP}_{3}$-releasable calcium stores. Insulin effects on ANG II-induced $\left[\mathrm{Ca}^{2+}\right]_{i}$ were mimicked by preincubation of VSMC with either sodium nitroprusside or 8-bromo-cGMP. As elevations in cGMP in vascular tissue lower $\left[\mathrm{Ca}^{2+}\right]_{i}$, it is possible that insulin affects $\mathrm{IP}_{3}$ release of calcium by a cGMP-dependent mechanism that would contribute to its vasodilatory effects. (J. Clin. Invest. 1993. 92:11611167.) Key words: cyclic nucleotides • hypotensive • inositol triphosphate $\bullet$ intracellular calcium stores $\bullet$ signal transduction
\end{abstract}

\section{Introduction}

Although a number of studies have emphasized the relationship between blood pressure and insulin in clinical and experimental hypertension (1-6), the direct effects of insulin on vascular tissue have yet to be clarified. While chronic hyperinsulinemia is thought to contribute to hypertension through several mechanisms including abnormal renal sodium han-

\footnotetext{
Address reprint requests to Dr. Michael Tuck, Division of Endocrinology (111E), Veterans Affairs Medical Center, UCLA School of Medicine, 16111 Plummer Street, Sepulveda, CA 91343.

Received for publication 27 October 1992 and in revised form 16 April 1993.
}

J. Clin. Invest.

(c) The American Society for Clinical Investigation, Inc.

$0021-9738 / 93 / 09 / 1161 / 07 \$ 2.00$

Volume 92, September 1993, 1161-1167 dling $(4,7,8)$, increased sympathetic nerve activity (8-10), and vascular reactivity (7), the acute action of insulin is vasodilatory as shown both in vivo (11-14), and in isolated vascular tissue $(15,16)$.

It is generally accepted that vasoactivity is, in part, modulated by alterations in cytosolic free calcium concentration (17). Recent studies have shown that insulin increases $\mathrm{Ca}^{2+}$-adenosine triphosphatase $\left(\mathrm{Ca}^{2+}\right.$-ATPase $)$ activity in the renal basolateral membrane (18) and that this effect is decreased in Zucker rats, an obese model of insulin resistance reported in some studies to be hypertensive (19). These observations might predict that the mechanism of insulin's acute vasodilatory actions occurs by alterations in $\mathrm{Ca}^{2+}$ pump activity and a decrease in intracellular calcium concentration. It follows then that chronic hyperinsulinemia and insulin resistance may contribute to the development of hypertension through impairment of this acute vasodilatory function.

This study examines the effect of insulin on angiotensin II (ANG II $)^{1}$-mediated intracellular calcium $\left[\mathrm{Ca}^{2+}\right]_{\mathrm{i}}$ and calcium mobilization in cultured rat vascular smooth muscle cells (VSMC). To clarify mechanisms, ANG II-receptor responses, calcium influx, ANG II-stimulated inositol 1,4,5-triphosphate $\left(\mathrm{IP}_{3}\right)$, and $\mathrm{IP}_{3}$ releasable calcium were measured in insulintreated VSMC. In addition, the role of cGMP as the mediator of insulin action was assessed.

\section{Methods}

Cell culture. VSMC were isolated from rat thoracic aorta (250-300-g male Sprague-Dawley rats) by enzymatic dispersion as previously described (20). The resulting cells were grown in Dulbecco's modified Eagle's medium (Sigma Chemical Co., St. Louis, MO) supplemented with $10 \%$ fetal calf serum (Intergen Co., Purchase, NY), $50 \mathrm{U} / \mathrm{ml}$ penicillin, and $50 \mu \mathrm{g} / \mathrm{ml}$ streptomycin (Sigma Chemical Co.). Confluent cultures were passed by treating with trypsin-EDTA and reseeding at a 1:4 ratio in fresh media. Cells (passages 4-12) were seeded onto $25-\mathrm{mm}$ round glass coverslips and reached confluence in 3-5 d. Before experimentation, cell lines were randomly screened for smooth muscle actin expression as assayed by immunofluorescent staining with antirat smooth muscle actin (Enzo Diagnostics Inc., New York) and visualized with fluorescein-conjugated rabbit anti-mouse IgG (Cappel Laboratories, Organon Teknica Corp., West Chester, PA).

Measurement of $\left[\mathrm{Ca}^{2+}\right]_{i}$. Confluent cells attached to the coverslips were deprived of serum for $24 \mathrm{~h}$ before study. Cells were loaded with 4 $\mu \mathrm{M}$ fura-2 acetoxymethylester (Molecular Probes, Inc., Eugene, OR) for $40 \mathrm{~min}$ at $37^{\circ} \mathrm{C}$ in physiologic salt solution (PSS; $143 \mathrm{mM} \mathrm{NaCl}, 5$

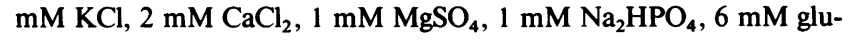
cose, and $10 \mathrm{mM}$ Hepes, $\mathrm{pH} 7.4$ ). Loaded cells were washed three times and then incubated with fresh PSS for an additional $15 \mathrm{~min}$ at

1. Abbreviations used in this paper: ANG II, angiotensin II; IGF, insulin-like growth factor; $\mathrm{IP}_{3}$, inositol 1,4,5-triphosphate; L-NMMA, L$\mathrm{N}^{\mathrm{G}}$-monomethyl-L-arginine; PSS, physiologic salt solution; TG, thapsigargin; VSMC, cultured vascular smooth muscle cells. 
$37^{\circ} \mathrm{C}$ to allow hydrolysis of the entrapped ester. Coverslips were then rinsed in fresh PSS, fixed to a specially designed chamber, and placed in a thermoregulated holder (maintained at $37^{\circ} \mathrm{C}$ ) on the microscopic stage. Photon emission was monitored at $510 \mathrm{~nm}$ with excitation wavelength alternating between 340 (F340) and $380 \mathrm{~nm}$ (F380) using a Deltascan spectrofluorometer (Photon Technology International, South Brunswick, NJ). At the end of each experiment, the minimum $\left(R_{\min }\right)$ and maximum $\left(R_{\max }\right)$ ratio of $\mathrm{F} 340$ and $\mathrm{F} 380(\mathrm{R} 340 / 380)$ was determined in PSS containing no added $\mathrm{Ca}^{2+}, 4 \mathrm{mM}$ EGTA and $1 \mu \mathrm{M}$ ionomycin and in PSS containing $10 \mathrm{mM} \mathrm{CaCl}_{2}$ and $1 \mu \mathrm{M}$ ionomycin, respectively. Each coverslip was individually corrected for autofluorescence by $\mathrm{Mn}^{2+}$ quenching and $\left[\mathrm{Ca}^{2+}\right]_{\mathrm{i}}$ was calculated according to the formula (21):

$\left[\mathrm{Ca}^{2+}\right]_{\mathrm{i}}=K_{\mathrm{d}} \times\left[\frac{\left(R-R_{\min }\right)}{\left(R_{\max }-R\right)}\right] \times \frac{\mathrm{Sf}_{2}}{\mathrm{Sb}_{2}}$,

where $K_{\mathrm{d}}$ represents the dissociation constant of fura-2 for calcium $(224 \mathrm{nM}), R$ represents the ratio of $\mathrm{F} 340 / \mathrm{F} 380, \mathrm{Sf}_{2}$ is the $\mathrm{F} 380$ intensity obtained from $R_{\min }$ (free fura-2), and $\mathrm{Sb}_{2}$ is the $\mathrm{F} 380$ when the dye is fully saturated with calcium collected during the $R_{\max }$ determination. Intracellular calcium responses to $100 \mathrm{nM}$ ANG II (Sigma Chemical Co.) were obtained in VSMC exposed to insulin (purified pork insulin, Regular ILETIN II, Eli Lilly \& Co., Indianapolis, IN) $10 \mu \mathrm{U} / \mathrm{ml}$ to 100 $\mathrm{mU} / \mathrm{ml}$. For short-term studies, cells were incubated for $20 \mathrm{~min}$ with insulin diluted in PSS and ANG II was added without changing the buffer in the well. For long-term studies, insulin was added for $24 \mathrm{~h}$ in serum-free medium. Short-term studies were also done comparing ANG II-induced $\left[\mathrm{Ca}^{2+}\right]_{\mathrm{i}}$ response with insulin to insulin-like growth factors (IGF-I or IGF-II; $2.5 \mathrm{ng} / \mathrm{ml}$, Intergen Co.).

ANG II receptors. ANG II receptors were estimated by displacement assay using a modification of standard techniques (22). Cells in six-well culture dishes were incubated in serum-free medium with or without added insulin at concentrations of $10 \mu \mathrm{U} / \mathrm{ml}$ to $1 \mathrm{mU} / \mathrm{ml}$ for $24 \mathrm{~h}$. Cells were then washed in cold PBS and incubated with $0.1 \mu \mathrm{Ci}$ ${ }^{125}$ I-ANG II (New England Nuclear, Boston, MA) and graded amounts of unlabeled ANG II from $1 \mathrm{nM}$ to $1 \mu \mathrm{M}$ for $4 \mathrm{~h}$ at $4^{\circ} \mathrm{C}$ in PBS containing $0.1 \%$ RIA grade BSA. Nonspecific background binding was determined by incubation with $50 \mu \mathrm{M}$ ANG II. Unbound ANG II was then removed by three washes in fresh buffer, and then cells hydrolyzed in $1.0 \mathrm{~N} \mathrm{NaOH}$ overnight. The resulting solution was then thoroughly mixed and a $0.5-\mathrm{ml}$ aliquot was counted in a Gamma 4000 scintillation counter (Beckman Instruments Inc., Palo Alto, CA). The binding affinity and receptor density of all curves were analyzed by Scatchard plotting using the computer program LIGAND by Munson and Robard (23).

Calcium influx. Manganese $\left(\mathrm{Mn}^{2+}\right)$ was used as a surrogate for $\mathrm{Ca}^{2+}$ for the estimation of calcium influx rates. $\mathrm{Mn}^{2+}$ uses the same influx channels as $\mathrm{Ca}^{2+}$ and has a very high affinity for fura-2, and binding of $\mathrm{Mn}^{2+}$ to the fura-2 molecule quenches its fluorescence (24). To test the effect of insulin on calcium influx rates, $20 \mathrm{mM} \mathrm{MnCl}_{2}$ was added to the incubation solution of fura-2-loaded VSMC. Total fluorescence was then monitored either by adding the $340-$ and $380-\mathrm{nm}$ signals, or by monitoring the photon emission at $360 \mathrm{~nm}$, the isosbestic wavelength for fura-2. The former method allows for simultaneous calculation of the calcium concentration. After a stable quench rate was established (usually 60-120 s) $100 \mathrm{mU}$ insulin was added and fluorescence followed. ANG II-induced calcium influx $\left(\mathrm{Mn}^{2+}\right.$ quench) was used as a positive control.

Measurement of ANG II-stimulated production of 1,4,5-IP ${ }_{3}$. For instantaneous $\mathrm{IP}_{3}$ measurements, confluent cells in six-well culture dishes were stimulated with $100 \mathrm{nM}$ ANG II for $15,30,60$, or $120 \mathrm{~s}$. For measurement of total $\mathrm{IP}_{3}$ production (phospholipase $\mathrm{C}$ activity), cells were incubated with ANG II for $5 \mathrm{~min}$ in the presence of $10 \mathrm{mM}$ $\mathrm{LiCl}$. In both experiments, reactions were stopped by addition of an equal volume of ice-cold $15 \%$ (wt/vol) TCA. The TCA was then removed by thrice washing with $10 \mathrm{vol}$ of water-saturated diethyl ether. Samples were then titrated to neutral $\mathrm{pH}$ with saturated sodium bicar- bonate, rapidly frozen, and lyophilized. Samples were subsequently reconstituted with distilled water, and $\mathrm{IP}_{3}$ was measured using a radioligand binding assay system (Amersham Corp., Arlington Heights, IL).

Intracellular release of calcium. The $\mathrm{IP}_{3}$-sensitive calcium pool was estimated using a modification of previously described methods (25). Briefly, confluent VSMC in 12-well culture dishes were loaded with 1 $\mu \mathrm{Ci} / \mathrm{ml}{ }^{45} \mathrm{Ca}$ (New England Nuclear) for $30 \mathrm{~min}$ at $37^{\circ} \mathrm{C}$. Loading, and all subsequent steps, were done in the presence of $5 \mathrm{mg} /$ liter ruthenium red to prevent uptake of calcium by the mitocondria and to block membrane $\mathrm{Ca}-\mathrm{Mg}$ ATPase activity and $\mathrm{Ca}$-induced $\mathrm{Ca}$ mobilization. Cells were washed twice with HBSS and incubated with $100 \mathrm{mU} / \mathrm{ml}$ insulin or HBSS without insulin for $5 \mathrm{~min}$ at ambient temperature. After removal of the treatment buffer, cells were treated with $35 \mu \mathrm{M}$ digitonin in Hepes buffer with or without $10 \mu \mathrm{M} \mathrm{IP}$ (Calbiochem Corp., San Diego, CA) for $5 \mathrm{~min}$, and then 1-ml aliquots were collected for counting. The $\mathrm{IP}_{3}$-sensitive $\mathrm{Ca}^{2+}$ was calculated by subtracting digitonin released ${ }^{45} \mathrm{Ca}$ from digitonin plus $\mathrm{IP}_{3}$-released ${ }^{45} \mathrm{Ca}$. In order to confirm these observations, spectrofluorometric experiments were also conducted to investigate the effect of insulin on the release of calcium by $10 \mu \mathrm{M}$ thapsigargin (TG) (26). Fura-2-loaded cells were preincubated with either $100 \mathrm{mU} / \mathrm{ml}$ insulin or heat-inactivated insulin for 20 min and then challenged with $10 \mu \mathrm{M}$ TG and $\left[\mathrm{Ca}^{2+}\right]_{i}$ calculated as described above. TG is known to release calcium from sarcoplasmic or endoplasmic reticulum and inhibit all isoforms of sarcoplasmic or endoplasmic reticulum Ca-ATPase (27).

Effect of CGMP on $\left[\mathrm{Ca}^{2+}\right]_{i}$ and IP ${ }_{3}$-releasable calcium. The effect of cGMP accumulation on $\left[\mathrm{Ca}^{2+}\right]_{\mathrm{i}}$ and $\mathrm{IP}_{3}$-releasable calcium was also tested in VSMC. VSMC were treated with $10 \mu \mathrm{M}$ 8-bromo-cGMP for 5 min before ANG II addition and determination of $\left[\mathrm{Ca}^{2+}\right]_{i}$. Sodium nitroprusside, which stimulates nitrous oxide and cGMP production, was also tested for $\mathrm{IP}_{3}$-sensitive calcium release in ${ }^{45} \mathrm{Ca}$-loaded VSMC. To test the effect of nitrous oxide inhibition on insulin attenuation of ANG II-induced $\left[\mathrm{Ca}^{2+}\right]_{i}$, fura-2-loaded VSMC were treated with 10 $\mu \mathrm{M} \mathrm{N}{ }^{\mathrm{G}}$-monomethyl-L-arginine (L-NMMA) (Calbiochem Corp.) for 5 min before insulin treatment and then stimulated with $100 \mathrm{nM}$ ANG II and $\left[\mathrm{Ca}^{2+}\right]_{\mathrm{i}}$ was determined.

Statistics. Results are expressed as mean \pm SEM. Studies with two groups were compared by unpaired Student's $t$ test. Studies with three or more groups were evaluated by analysis of variance (ANOVA) with subset analysis by Tukey contrast.

\section{Results}

Insulin dose effect on ANG II-stimulated $\left[\mathrm{Ca}^{2+}\right]_{i} .20 \mathrm{~min}$ of incubation with insulin alone did not alter basal $\left[\mathrm{Ca}^{2+}\right]_{\mathrm{i}}$ level in VSMC (Fig. 1). However, mean ANG II-induced $\left[\mathrm{Ca}^{2+}\right]_{i}$ levels were inhibited by 20 -min insulin incubations in a dosedependent manner (Fig. 1). Fig. 2 is a representative time course for ANG II-induced $\left[\mathrm{Ca}^{2+}\right]_{\mathrm{i}}$ responses showing that $\left[\mathrm{Ca}^{2+}\right]_{\mathrm{i}}$ responses were inhibited by 20 -min addition of 1 and $100 \mathrm{mU} / \mathrm{ml}$ insulin. Cross-reactivity of insulin with IGF receptors in VSMC was also tested. The potency of insulin to displace ${ }^{125}$ I-IGF is $1,000-2,000$ times less than IGF itself as studied in rat cultured VSMC $(28,29)$. Therefore, control studies were performed using $2.5 \mathrm{ng} / \mathrm{ml}$ IGF-I and IGF-II, a concentration that does not significantly cross-react with other receptors $(29,30)$, but is approximately equivalent to the displacement of IGFs from their receptors by $100 \mathrm{mU} / \mathrm{ml}$ insulin. Fig. 3 shows mean basal and ANG II-stimulated peak $\left[\mathrm{Ca}^{2+}\right]_{\mathrm{i}}$ from control, $100 \mathrm{mU} / \mathrm{ml}$ insulin, $2.5 \mathrm{ng} / \mathrm{ml}$ of IGF-I- or IGF-IItreated VSMC. Insulin attenuated ANG II-stimulated $\left[\mathrm{Ca}^{2+}\right]_{i}$, whereas IGF-I and IGF-II did not significantly alter $\left[\mathrm{Ca}^{2+}\right]_{i}$ responses.

Extracellular calcium and calcium influx studies. To evaluate the contribution of extracellular calcium to insulin's effect 


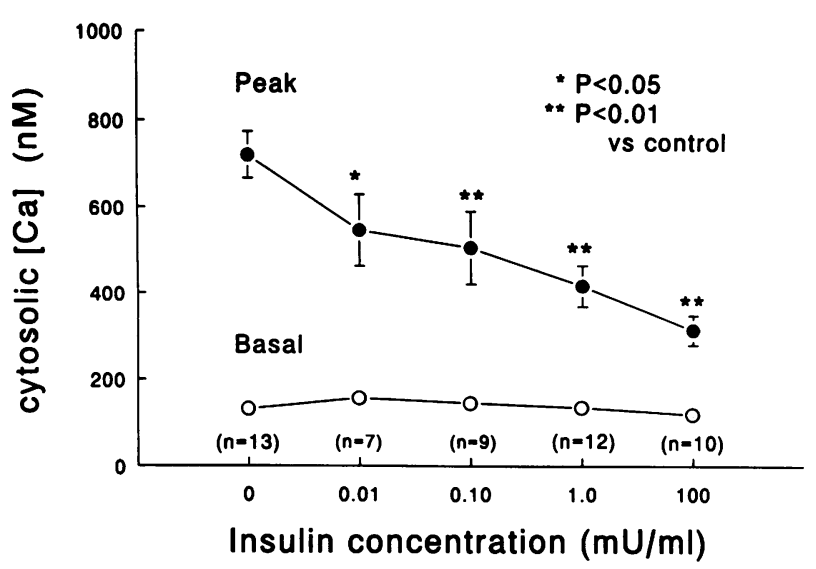

Figure 1. Effect of insulin on ANG II-induced calcium transients. Mean \pm SEM basal $\left[\mathrm{Ca}^{2+}\right]_{i}(0)$, and peak responses $(\bullet)$ to $100 \mathrm{nM}$ ANG II after 20-min of preincubation with control buffer or $10 \mu \mathrm{U} /$ $\mathrm{ml}$ to $100 \mathrm{mU} / \mathrm{ml}$ insulin. No changes in basal $\left[\mathrm{Ca}^{2+}\right]_{\mathrm{i}}$ are noted but peak responses show a dose-dependent decrease in ANG II-induced $\left[\mathrm{Ca}^{2+}\right]_{\mathrm{i}}$ responses to insulin.

on ANG II-induced $\left[\mathrm{Ca}^{2+}\right]_{\mathrm{i}}$ responses, $4 \mathrm{mM}$ EGTA was added to the medium $19 \mathrm{~min}$ after insulin and $1 \mathrm{~min}$ before ANG II addition. There was no difference in basal $\left[\mathrm{Ca}^{2+}\right]_{\mathrm{i}}$ in control VSMC and VSMC exposed for $20 \mathrm{~min}$ to $100 \mathrm{mU} / \mathrm{ml}$ of insulin (Fig. 4). However, ANG II-stimulated $\left[\mathrm{Ca}^{2+}\right]_{\mathrm{i}}$ responses were significantly attenuated in insulin-treated VSMC (Fig. 4). Importantly, the percent attenuation of ANG II-induced $\left[\mathrm{Ca}^{2+}\right]_{\mathrm{i}}$ responses by $100 \mathrm{mU} / \mathrm{ml}$ insulin was similar in these experiments to studies using $2 \mathrm{mM}$ extracellular $\mathrm{CaCl}_{2}$.

Calcium influx was determined using $\mathrm{Mn}^{2+}$ quenching of fura-2 in VSMC in the presence of ANG II or insulin (Fig. 5). ANG II addition to $\mathrm{Mn}^{2+}$-treated VSMC induced $\mathrm{Ca}^{2+}$ influx as demonstrated by an increase in the quench rate of the total fluorescence whereas insulin had no effect on $\mathrm{Mn}^{2+}$ quenching of fura-2 fluorescence.

Effect of $24 \mathrm{~h}$ of insulin treatment on ANG II-stimulated $\left[\mathrm{Ca}^{2+}\right]_{i}$. Fig. 6 shows that basal $\left[\mathrm{Ca}^{2+}\right]_{\mathrm{i}}$ levels in VSMC preincubated for $24 \mathrm{~h}$ with $10 \mu \mathrm{U} / \mathrm{ml}$ to $10 \mathrm{mU} / \mathrm{ml}$ insulin did not change from control. However, 24-h insulin treatment attenuated ANG II-induced $\left[\mathrm{Ca}^{2+}\right]_{\mathrm{i}}$ responses at doses of $100 \mu \mathrm{U} /$ $\mathrm{ml}$ or higher.

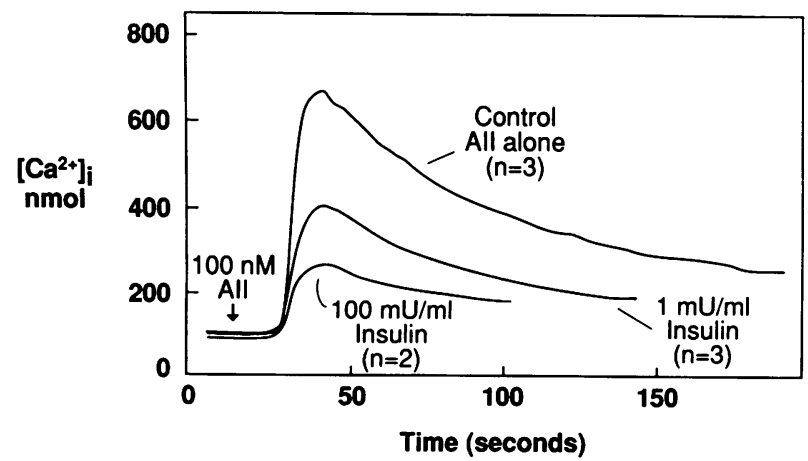

Figure 2. Time course of calcium transients. $\left[\mathrm{Ca}^{2+}\right]_{\mathrm{i}}$ responses to 100 nM ANG II after 20 min of preincubation with control buffer $(n$ $=3), 1 \mathrm{mU} / \mathrm{ml}(n=2)$, and $100 \mathrm{mU} / \mathrm{ml}(n=3)$ insulin. Time 0 in the figure begins after $19 \mathrm{~min}$ of insulin treatment. Observed time course curves from $1 \mathrm{~d}$ were averaged at each concentration.

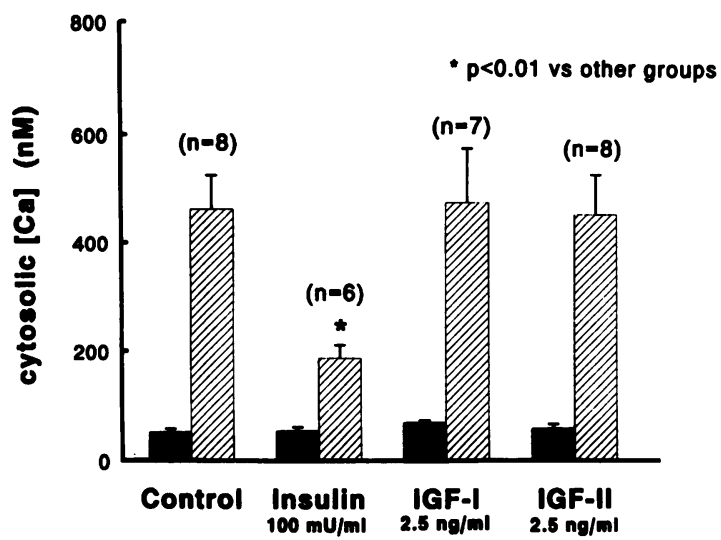

Figure 3. Comparison of insulin to IGF-I and IGF-II on $\left[\mathrm{Ca}^{2+}\right]_{\mathrm{i}}$. Mean \pm SEM basal $\left[\mathrm{Ca}^{2+}\right]_{\mathrm{i}}$ (solid bars) and peak responses (hatched bars) to $100 \mathrm{nM}$ ANG II after $20 \mathrm{~min}$ of incubation with control buffer, $100 \mathrm{mU} / \mathrm{ml}$ insulin, and $2.5 \mathrm{ng} / \mathrm{ml}$ of IGF-I and IGF-II. No differences were observed in ANG II-induced $\left[\mathrm{Ca}^{2+}\right]_{i}$ in responses to IGF-I or IGF-II.

Effect of insulin on ${ }^{125}$ I-ANG II binding. Competitive binding displacement of ${ }^{125}$ I-ANG II in VSMC was not altered by incubation $(24 \mathrm{~h})$ in serum-free media with $0.05,0.10,0.5$, and $1.00 \mathrm{mU} / \mathrm{ml}$ of insulin (Table I). Scatchard plot results show no significant changes in ANG II receptor density or affinity over the concentration range of insulin studied.

Effect of insulin on ANG II-stimulated 1,4,5-IP ${ }_{3}$ production. VSMC incubated with four doses of insulin for $24 \mathrm{~h}$ showed a dose-dependent increase in mean values for peak ANG II-induced $\mathrm{IP}_{3}$ production (Fig. 7). However, acute insulin incubation $\left(20 \mathrm{~min}\right.$ ) had no effect on peak $\mathrm{IP}_{3}$ production ( 30 s after ANG II stimulation ). Phospholipase C activity (estimated by $\mathrm{IP}_{3}$ production in the presence of $10 \mathrm{mM} \mathrm{LiCl}$ ) was also not altered by acute insulin incubation.

Effect of insulin on $\mathrm{IP}_{3}$-releasable ${ }^{45} \mathrm{Ca}$. The effect of insulin on intracellular calcium stores was examined using $\mathrm{IP}_{3}$-mediated release of ${ }^{45} \mathrm{Ca}$ from permeabilized VSMC preloaded with ${ }^{45} \mathrm{Ca}$. Incubation of ${ }^{45} \mathrm{Ca}$-loaded VSMC with $100 \mathrm{mU} / \mathrm{ml}$

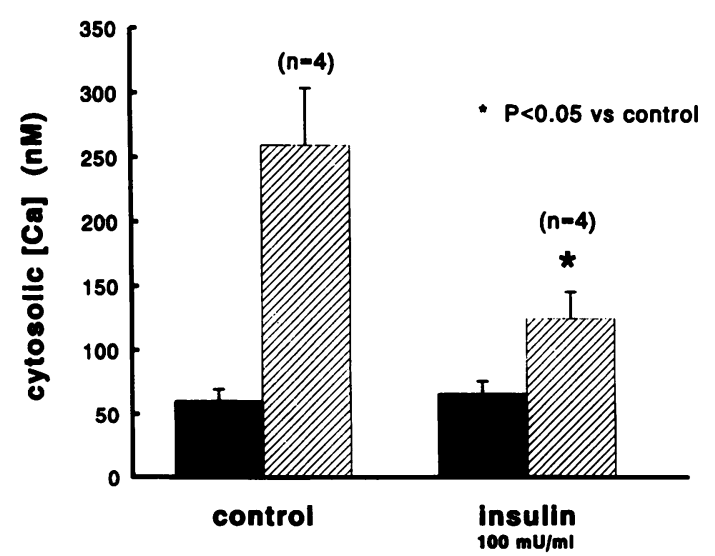

Figure 4. Effect of insulin on ANG II-induced $\left[\mathrm{Ca}^{2+}\right]_{\mathrm{i}}$ calcium-poor buffer. Mean \pm SEM basal $\left[\mathrm{Ca}^{2+}\right]_{\mathrm{i}}$ (solid bars) and peak responses (hatched bars) to $100 \mathrm{nM}$ ANG II after 20 min of incubation with control buffer and $100 \mathrm{mU} / \mathrm{ml}$ insulin in calcium chelated medium. Insulin also attenuates ANG II-induced $\left[\mathrm{Ca}^{2+}\right]_{\mathrm{i}}$ responses at a reduced $\mathrm{Ca}^{2+}$ gradient. 


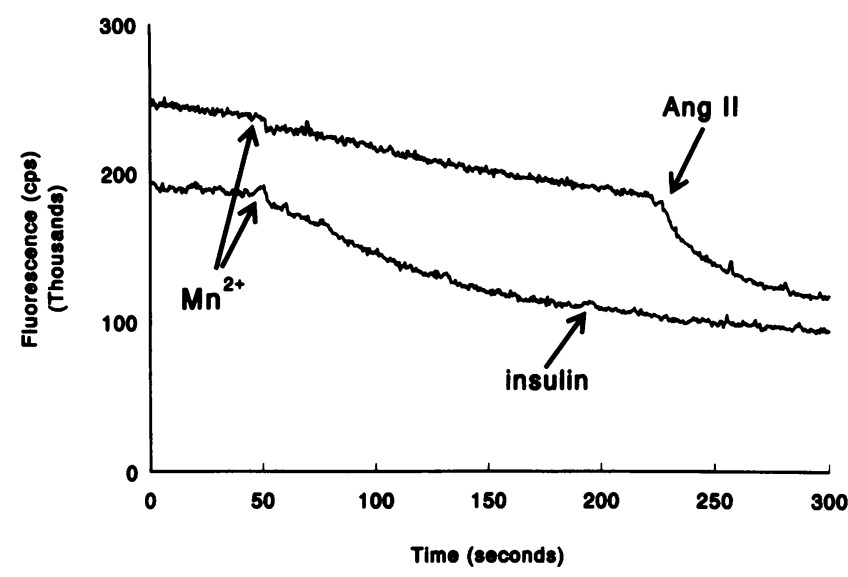

Figure 5. Effect of ANG II and insulin on Manganese influx. Fluorescence decay curves of fura 2-loaded VSMC over $300 \mathrm{~s}$ with addition of $\mathrm{Mn}^{2+}$ at $50 \mathrm{~s}$ and subsequent addition of ANG II or insulin between 200 and 240 s. Ang II reduces, whereas insulin has no effect on, $\mathrm{Mn}^{2+}$ quenching.

insulin caused a marked reduction $(P<0.05)$ in percentage from baseline of $\mathrm{IP}_{3}$-releasable ${ }^{45} \mathrm{Ca}$ (Fig. 8). Ruthenium red was used to isolate $\mathrm{IP}_{3}$-mediated calcium release from sarcoplasmic reticulum by blocking ${ }^{45} \mathrm{Ca}$ uptake in the mitochondria (25). Ruthenium red also blocks membrane Ca-Mg ATPase activity ( 31 ), and calcium-mediated Ca release from sarcoplasmic reticulum (32).

TG releases calcium from intracellular stores and prevents its reuptake, so it can be used as a means to estimate intracellular calcium pools $(26)$. TG $(10 \mu \mathrm{M})$ increased $\left[\mathrm{Ca}^{2+}\right]_{i}$ from a basal level of $126.4 \pm 9.4$ to $210.3+21.6 \mathrm{nM}$ (Fig. 9). Preincubation with $100 \mathrm{mU} / \mathrm{ml}$ insulin for $20 \mathrm{~min}$ completely inhibited TG-induced $\left[\mathrm{Ca}^{2+}\right]_{\mathrm{i}}$ responses in VSMC indicating that its effect on reducing mobilization of calcium is from the same pool as TG effects.

Effect of cGMP on $\left[\mathrm{Ca}^{2+}\right]_{i}$ and $\mathrm{IP}_{3}$-releasable calcium. In fura 2-loaded VSMC, 5-min incubations with $10 \mu \mathrm{M}$ of the

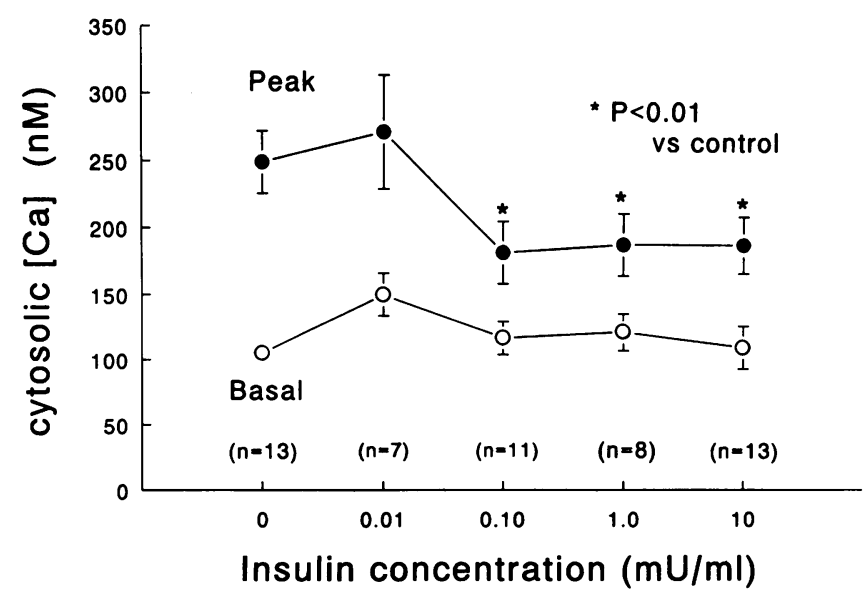

Figure 6. ANG II-mediated $\left[\mathrm{Ca}^{2+}\right]_{\mathrm{i}}$ responses after $24 \mathrm{~h}$ of incubation with insulin. Basal $\left[\mathrm{Ca}^{2+}\right]_{\mathrm{i}}(\mathrm{O})$, and peak responses $(\bullet)$ to $100 \mathrm{nM}$ ANG II after $24 \mathrm{~h}$ of incubation with $0-10 \mathrm{mU} / \mathrm{ml}$ insulin. No significant differences are observed in basal $\left[\mathrm{Ca}^{2+}\right]_{i}$, however insulin attenuates peak ANG II-induced $\left[\mathrm{Ca}^{2+}\right]_{\mathrm{i}}$ responses at doses of 100 $\mu \mathrm{U} / \mathrm{ml}$ or higher.
Table I. Effect of Insulin on ANG II Receptor Number and Affinity

\begin{tabular}{ccr}
\hline [Insulin] & $B_{\max }$ & \multicolumn{1}{c}{$K_{\mathrm{d}}$} \\
\hline$m U / m l$ & $\times 10^{-11}$ & $\times 10^{-9}$ \\
Control & $3.74 \pm 0.73$ & $14.6 \pm 3.6$ \\
0.05 & $4.80 \pm 0.48$ & $12.6 \pm 2.2$ \\
0.10 & $2.50 \pm 0.27$ & $7.6 \pm 1.1$ \\
0.50 & $4.09 \pm 0.22$ & $19.0 \pm 1.3$ \\
1.00 & $3.09 \pm 0.78$ & $13.1 \pm 4.1$
\end{tabular}

Scafit estimates of maximal binding $\left(B_{\max }\right)$ and dissociation constant $\left(K_{d}\right) \pm$ residual variances as estimated from iterative curve fits of triplicate determinations of competative binding displacement of ${ }^{125} \mathrm{I}$ ANG II by increasing concentrations of unlabeled ANG II. No differences were observed in ANG II receptor density or affinity after 24-h of incubation with insulin.

cell-permeable, cGMP mimetic, 8-bromo-cGMP, attenuated mean ANG II-induced $\left[\mathrm{Ca}^{2+}\right]_{i}$ levels (change in $\left[\mathrm{Ca}^{2+}\right]_{\mathrm{i}}$ : $306.5 \pm 50.7$ for control vs. $119.8 \pm 20.0$ for 8 -bromo-cGMP, $P$ $<0.01$ ). Fig. 10 shows a representative tracing from these experiments. In addition, incubation of VSMC with 8-bromocGMP blocked release of calcium by $\mathrm{IP}_{3}$ as did addition of the nitrous oxide agonist sodium nitroprusside ( $50 \mu \mathrm{M}$ ) (data not shown).

Cultured VSMC have been shown to generate L-argininederived NO through pathways that are not sensitive to acetylcholine or bradykinin (33). Fig. 11 shows that pretreatment of VSMC with $10 \mu \mathrm{M}$ of the NO inhibitor L-NMMA blocked the effect of insulin to attenuate ANG II-induced $\left[\mathrm{Ca}^{2+}\right]_{\mathrm{i}}$ responses.

\section{Discussion}

One mechanism for insulin's vasodilatory action in vascular tissue may be through alterations in intracellular calcium metabolism. This action on calcium is not seen with insulin incubation alone, but appears to be an effect to interfere with pressor hormone mobilization of calcium in vascular cells. Insulin consistently produced a dose-dependent inhibition of ANG IIinduced $\left[\mathrm{Ca}^{2+}\right]_{i}$ responses. This effect on pressor hormone action may not be confined to ANG II in that arginine vasopressin-induced calcium transients in cultured VSMC are also in-

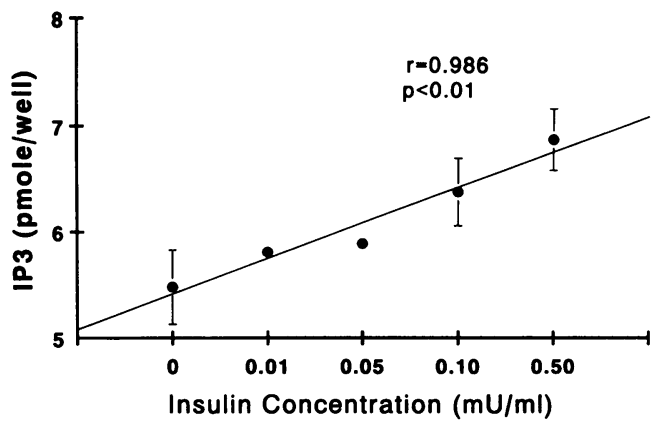

Figure 7. ANG II-mediated $\mathrm{IP}_{3}$ responses after $24 \mathrm{~h}$ of incubation with insulin. Mean \pm SEM of triplicate determinations of the $\mathrm{IP}_{3}$ response $30 \mathrm{~s}$ after ANG II stimulation. There are no significant changes in mean $\mathrm{IP}_{3}$ responses with insulin. 


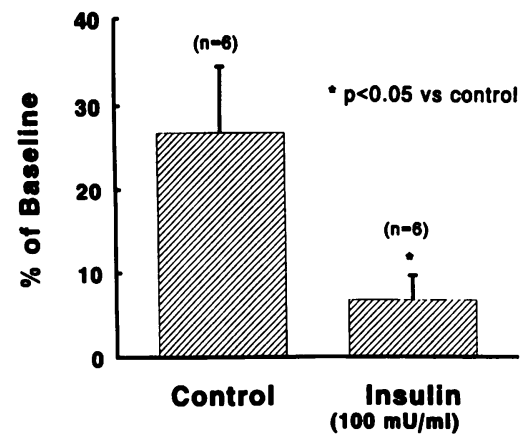

hibited by insulin (34). Moreover, Kahn et al. (35) recently demonstrated reduced insulin attenuation of seratonin induced contraction and $\left[\mathrm{Ca}^{2+}\right]_{\mathrm{i}}$ in canine femoral artery VSMC. The dramatic effect of insulin to block $\mathrm{IP}_{3}$-sensitive and TG sensitive calcium release indicates that its primary site of action is on intracellular calcium release from the sarcoplasmic reticulum. Although there may be effects of insulin on membrane calcium fluxes in vascular tissue, these appeared minimal in our studies because insulin's action was retained in calcium poor medium. There was also ro influence of insulin on manganese influx, a newer method to measure real-time changes in calcium influx through calcium channels. In that stimulation of intracellular cGMP production with nitroprusside and 8bromo-cGMP duplicated the effect of insulin on cytosolic calcium and $\mathrm{IP}_{3}$-sensitive calcium release, we believe that insulin is acting through cyclic nucleotide pathways in altering calcium mobilization. It is thought that one of insulin's intracellular effects is to changes cyclic nucleotide metabolism (36) and elevation of cGMP in vascular tissue has been shown to reduce intracellular calcium (37). Insulin regulation of calcium in vascular cells may be via a cGMP-dependent pathway such as cGMP-dependent protein kinase or by regulation of phosphodiesterases, as has been demonstrated in hepatocytes and adipocytes $(38,39)$.

There are other mechanisms not tested in the present study to explain insulin's effect on calcium in blood vessels. The $\mathrm{Na}^{+} / \mathrm{Ca}^{2+}$ exchanger and the $\mathrm{Ca}^{2+}$-ATPase systems are present in VSMC to maintain a positive $\mathrm{Ca}^{2+}$ gradient (40-43). Insulin stimulates $\mathrm{Ca}^{2+}$-ATPase activity in dog and rat kidney

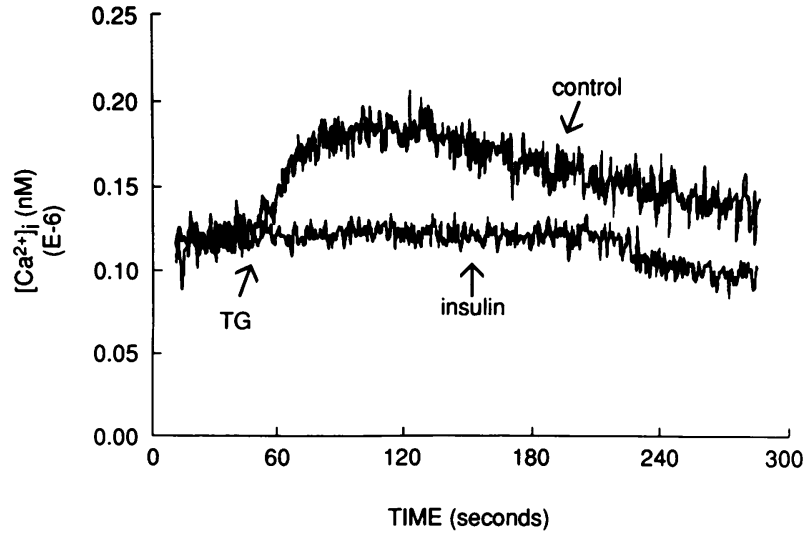

Figure 9. Effect of insulin on TG-induced $\left[\mathrm{Ca}^{2+}\right]_{\mathrm{i}}$ responses. $\left[\mathrm{Ca}^{2+}\right]_{\mathrm{i}}$ responses over $300 \mathrm{~s}$ to $\mathrm{TG}(10 \mu \mathrm{M})$ in control and $100 \mathrm{mU} / \mathrm{ml}$ insulin-treated VSMC. TG $\left[\mathrm{Ca}^{2+}\right]_{i}$ responses are reduced in the presence of insulin.

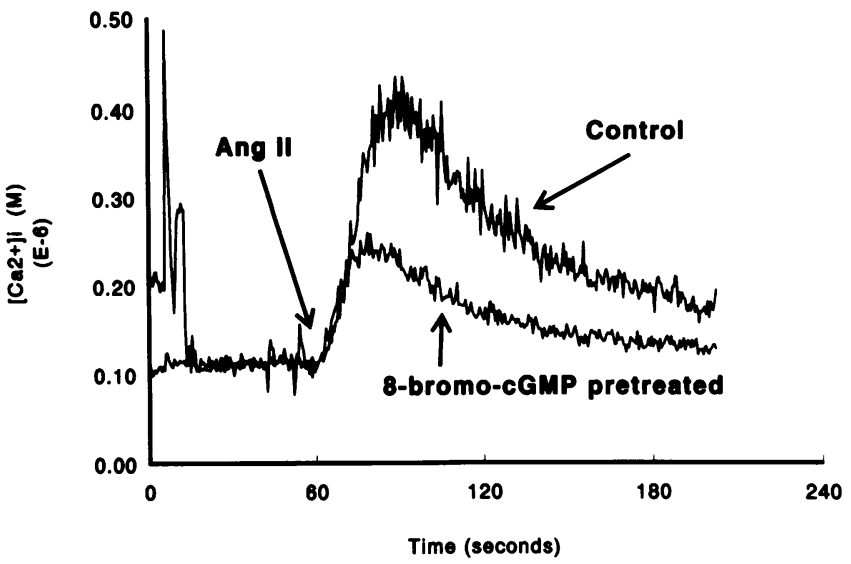

Figure 10. Effect of 8-bromo-cGMP on ANG II-induced $\left[\mathrm{Ca}^{2+}\right]_{\mathrm{i}}$ responses. $\left[\mathrm{Ca}^{2+}\right]_{i}$ responses over $200 \mathrm{~s}$ to $100 \mathrm{nM}$ ANG II in control and 8-bromo-cGMP-treated $(10 \mu \mathrm{M})$ VSMC. $\left[\mathrm{Ca}^{2+}\right]_{\mathrm{i}}$ responses are reduced with 8-bromo-cGMP.

basolateral membranes $(18,44)$. $\mathrm{Ca}^{2+}$-ATPase activity is reported decreased in kidney basolateral membranes in Zucker obese rats (19), an animal model of insulin resistance and hypertension (1). Decreased ${ }^{45} \mathrm{Ca}$ efflux is also seen in ${ }^{45} \mathrm{Ca}$ loaded aortic strips from Zucker obese rats (45). However, in the present study we demonstrate effects of insulin that are probably independent of changes in the $\mathrm{Ca}^{2+}$-ATPase pump. Since $\mathrm{IP}_{3}$ release of ${ }^{45} \mathrm{Ca}$ was done in the presence of ruthenium red which blocks $\mathrm{Ca}^{2+}$-ATPase, attenuation of calcium release from these stores by insulin must be from other mechanisms. Insulin has also been shown to stimulate the $\mathrm{Na}^{+}-\mathrm{K}^{+}$pump (46), which leads to secondary increases in $\mathrm{Na}^{+} / \mathrm{Ca}^{2+}$ exchange. This mechanism was not tested in our studies.

The affinity and density of ANG II receptors were not altered by 24-h incubation of VSMC with insulin and ANG IIstimulated phospholipase $\mathrm{C}$ activity was also unchanged. These findings indicate that insulin attenuation of Ang II-stimulated $\left[\mathrm{Ca}^{2+}\right]_{\mathrm{i}}$ responses is not by its receptor or immediate postreceptor signaling mechanisms. $\mathrm{IP}_{3}$ formation is mediated by agonists such as ANG II, releasing calcium from intracellular stores in vascular smooth muscle cells (47). We observed no

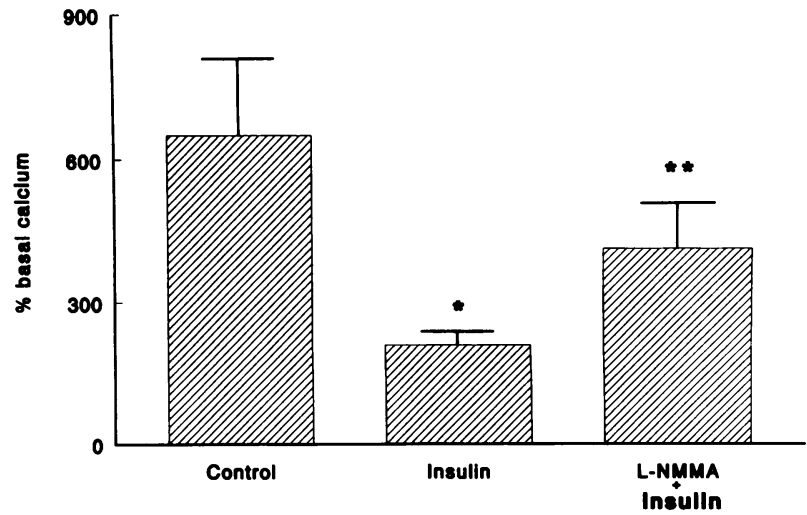

Figure 11. Effect of L-NMMA on $\left[\mathrm{Ca}^{2+}\right]_{\mathrm{i}}$ responses to ANG II. Mean \pm SEM $\left[\mathrm{Ca}^{2+}\right]_{\mathrm{i}}$ responses to ANG II (\% over basal) during control, insulin, and insulin plus L-NMMA. Insulin reduces mean $\left[\mathrm{Ca}^{2+}\right]_{\mathrm{i}}$ responses to ANG II, whereas insulin + L-NMMA mean $\left[\mathrm{Ca}^{2+}\right]_{\mathrm{i}}$ is not different from control. ${ }^{*} P<0.05$ vs. control; ${ }^{* *} P$ $<0.05$ vs. insulin alone. 
change in $\mathrm{IP}_{3}$ production in vascular cells after $20 \mathrm{~min}$ of incubation with insulin but noted a modest dose-dependent increase in $\mathrm{IP}_{3}$ after 24-h exposure. However, in the acute studies, despite no alterations in $\mathrm{IP}_{3}$ production, there was a decrease in $\mathrm{IP}_{3}$-releasable ${ }^{45} \mathrm{Ca}$ with insulin treatment. Thus, insulin affects calcium not by altering $\mathrm{IP}_{3}$ levels but by changing the sensitivity of $\mathrm{IP}_{3}$ for calcium release or by depleting $\mathrm{IP}_{3}$-releasable intracellular calcium stores.

When insulin is administered in vivo or added to in vitro vessel preparations, most studies find an acute vasodilatory response. For example, hypotension with insulin treatment has been reported in diabetic patients with the complications of diabetic neuropathy (11). Other studies in humans have also noted an acute dose-dependent vasodilatory effect of insulin (12-14). Infusion of increasing doses of insulin by euglycemic clamp in normal controls causes a substantial increase in leg blood flow suggesting a generalized vasodilator response (48). Interestingly, at the same doses of infused insulin, obese subjects have less increase in leg blood flow: results that could be interpreted to show resistance to insulin's vasodilatory action in the blood vessels of the obese. In vitro vascular preparation experiments also show that incubation with insulin for 30-120 min attenuates the vasoconstrictor response to norepinephrine in the resistance bed of the isolated perfused rat tail (15). Yagi et al. (16) performed extensive studies with rabbit femoral arteries and veins showing that 30 -min incubations with insulin dose-dependently inhibits the vasoconstrictive responses to norepinephrine and Ang II.

Although the role of insulin as a regulator of cell calcium remains controversial, several effects on calcium mobilization and pump activity have been reported. Insulin has been found to alter calcium metabolism in skeletal tissue (49-51), cardiac muscle cells (52), adipocytes $(51,53)$, and kidney tissue $(18$, $19)$. Insulin-mediated increases in calcium efflux as studied in ${ }^{45} \mathrm{Ca}$ preloaded cells, have been reported in rat adipocytes and soleus muscle (51). It is not clear, however, what effect this insulin-mediated calcium efflux had on intracellular calcium. In another study insulin addition to adipocytes did increase cytosolic calcium (54). Direct effects of insulin on calcium channels have also been demonstrated in cultured skeletal muscle cells. In primary cultured rat embryo hindlimb muscle cells, 5-6 min of incubation with insulin inhibits depolarization-induced calcium inward current (50). However, in cultured human muscle cells, more prolonged ( $2 \mathrm{wk}$ ) treatment with insulin potentiates $40 \mathrm{mM} \mathrm{K}{ }^{+}$induced ${ }^{45} \mathrm{Ca}^{2+}$ uptake (49). From these findings, it has been proposed that insulin acutely induces a vasodilator action by altering intracellular calcium metabolism. The present study supports these findings and offers an additional mechanism of action.

In contrast to insulin's acute vasodilating action, other reports have described potential hypertensive effects of insulin. Yanagisawa-Miwa et al. (55) observed an enhancing effect of insulin (incubation for $120 \mathrm{~min}$ ) on contraction to a thromboxane $A_{2}$ analogue in porcine coronary artery. Potentiation by insulin might be selective for this agonist, since no enhancing effect was observed with high $\mathrm{K}^{+}$, norepinephrine, histamine, or serotonin-induced contractions. In alloxan- or streptozotocin-induced diabetic animals, insulin reverses diabetesinduced inhibition of vascular smooth muscle contractility $(56,57)$ and long-term $(8-12 \mathrm{wk})$ insulin therapy tended to increase vascular contractility to high potassium (57). Our laboratory has reported increased pressor responses to graded- dose ANG II infusions in normotensive and hypertensive noninsulin-dependent diabetic patients (7). These patients were obese with varying degrees of insulin resistance and insulinemia. The fact that acute studies demonstrate a vasodilatory effect of insulin whereas more chronic exposure results in a vasoconstrictor effect suggest a transition in insulin's vascular actions with exposure over time. One hypothesis suggests that chronic hyperinsulinemia may cause vascular hypereactivity by a desensitization of its acute vasodilatory effect as was shown in the study of obese subjects where leg blood flow responses to insulin were reduced (48).

In summary, our findings suggest that insulin attenuates ANG II-stimulated increases in $\left[\mathrm{Ca}^{2+}\right]_{\mathrm{i}}$ in VSMC by decreasing the pool of $\mathrm{IP}_{3}$-releasable calcium. In addition, these studies demonstrate that insulin's effects can be mimicked by treatment of VSMC with a cGMP analogue (8-bromo-cGMP) or stimulation of a cGMP generating system (Na-nitroprusside). Moreover, we have demonstrated that inhibition of argininederived NO generation blocks insulin's effects on $\mathrm{IP}_{3}$-sensitive $\mathrm{Ca}^{2+}$ release. This effect may explain the acute vasodilatory action of insulin, however, the chronic effects of insulin on calcium metabolism and vascular reactivity are yet to be clarified.

\section{Acknowledgments}

The authors would like to thank Patricia Wilsey and Sherry Wu for excellent technical support and Andrew Tuck for assistance in the preparation of the manuscript.

This study was supported by Department of Veterans Affairs Merit Review Funds and by National Institutes of Health grant 5 P50 HL44404 SCOR in Hypertension, Willa Hsueh, Principal Investigator.

\section{References}

1. Kurtz, T. W., C. Morris, and H. A. Pershadsingh. 1989. The Zucker fatty rat as a genetic model of obesity and hypertension. Hypertension. 13:896-901.

2. Reaven, G. M., H. Ho, and B. B. Hoffman. 1989. Somatostatin inhibition of fructose-induced hypertension. Hypertension. 14:117-120.

3. Modan, M., H. Halkin, S. Almog, A. Lusky, A. Eshkol, M. Shefi, A. Shitrit, and Z. Fuchs. 1985. Hyperinsulinemia: a link between hypertension obesity and glucose intolerance. J. Clin. Invest. 75:809-817.

4. Rocchini, A. P., J. Key, D. Bondie, R. Chico, C. Moorehead, V. Katch, and M. Martin. 1989. The effect of weight loss on the sensitivity of blood pressure to sodium in obese adolescents. $N$. Engl. J. Med. 321:580-585.

5. Rose, H. G., R. S. Yalow, P. Schweitzer, and E. Schwartz. 1986. Insulin as a potential factor influencing blood pressure in amputees. Hypertension. 8:793800 .

6. Swislocki, A. L. M., B. B. Hoffman, and G. M. Reaven. 1989. Insulin resistance, glucose intolerance and hyperinsulinemia in patients with hypertension. Am. J. Hypertens. 2:419-423.

7. Tuck, M. L., D. Corry, and A. Trujillo. 1990. Salt-sensitive blood pressure and exaggerated vascular reactivity in the hypertension of diabetes mellitus. $\mathrm{Am}$. J. Med. 88:210-216.

8. Yokota, M., K. Shimoda, Y. Kobayashi, and N. Kajiwara. 1989. Insulin and hypertension: the mechanisms of high blood pressure during chronic insulin infusion. Jpn. J. Nephrol. 31:875-881.

9. Rowe, J. W., J. B. Young, K. L. Minaker, A. L. Stevens, J. Pallotta, and L. Landsberg. 1981. Effect of insulin and glucose infusions on sympathetic nervous activity in normal man. Diabetes. 30:219-225.

10. Sowers, J. R., L. A. Whitfield, R. A. Catania, N. Stern, M. L. Tuck, L. Dornfeld, and M. Maxwell. 1982. Role of the sympathetic nervous system in blood pressure maintenance in obesity. J. Clin. Endocrinol. Metab. 54:11811186.

11. Page, M., and P. J. Watkins. 1976. Provocation of postural hypotension by insulin in diabetic autonomic neuropathy. Diabetes. 25:90-95.

12. Liang, C., J. U. Doherty, R. Faillace, K. Maekawa, S. Arnold, H. Gavras, and W. B. Jr. Hood. 1982. Insulin infusion in conscious dogs: effects on systemic and coronary hemodynamics, regional blood flows, and plasma catecholamines. J. Clin. Invest. 69:1321-1336.

13. Takata, S., M. Yamamoto, S. Yagi, Y. Noto, T. Ikeda, and N. Hattori. 1985. Peripheral circulatory effects of insulin in diabetes. Angiology. 36:1 10-115. 
14. Downing, S. E., J. C. Lee, and D. N. Matisoff. 1980. Coronary blood flow in the diabetic lamb with metabolic acidosis. Am. J. Physiol. 238:H263-H268.

15. Alexander, W. D., and R. J. Oake. 1977. The effect of insulin on vascular reactivity to norepinephrine. Diabetes. 26:611-614.

16. Yagi, S., S. Takata, and H. Kiyokawa. 1988. Effects of insulin on vasoconstrictive responses to norepinephrine and angiotensin II in rabbit femoral arterty and vein. Diabetes. 37:1064-1067.

17. Sato, K., H. Ozaki, and H. Karaki. 1988. Changes in cytosolic calcium level in vascular smooth muscle strip measured simultaneously with contraction using fluorescent calcium indicator fura 2. J. Pharmacol. Exp. Ther. 246:294300.

18. Levy, J., J. R. Gavin III, S. Morimoto, M. R. Hammerman, and L. V. Avioli. 1986. Hormonal regulation of $\left(\mathrm{Ca}^{2+}+\mathrm{Mg}^{2+}\right)$ ATPase activity in canine renal basolateral membrane. Endocrinology. 119:2405-2411.

19. Levy, J., and D. Rempinski. 1989. A hormone specific defect in insulin regulation of the membrane $\left(\mathrm{Ca}^{2+}+\mathrm{Mg}^{2+}\right)$-ATPase in obesity. Clin. Res. 37:455A. (Abstr.)

20. Brock, T. A., L. J. Lewis, and J. B. Smith. 1982. Angiotensin II increases $\mathrm{Na}^{+}$entry and $\mathrm{Na}^{+} / \mathrm{K}^{+}$pump activity in smooth muscle from rat aorta. Proc. Natl. Acad. Sci. USA. 79:1438-1442.

21. Grynkiewicz, G., M. Poenie, and R. Y. Tsien. 1985. A new generation of $\mathrm{Ca}^{2+}$ indicators with greatly improved fluorescence properties. J. Biol. Chem. 260:3340-3450.

22. Gunther, S., R. W. Alexander, W. J. Atkinson, and M. A. Gimbrone, Jr. 1982. Functional angiotensin II receptors in cultured vascular smooth muscle cells. J. Cell Biol. 92:289-298.

23. Munson, P. J., and D. Rodbard. 1980. Ligand: a versitile computerized approach for characterization of ligand-binding systems. Anal. Biochem. 107:220-239.

24. Simpson, A. W., A. Stampfl, and C. C. Ashley. 1990. Evidence for receptor-mediated bivalent-cation entry in A10 vascular smooth-muscle cells. Biochem. J. 267:277-280.

25. Fittingoff, M., and J. F. Krall. 1988. Changes in inositol polyphosphatesensitive calcium exchange in aortic smooth muscle cells in vitro. J. Cell. Physiol. 134:297-301.

26. Thastrup, O., P. J. Cullen, B. K. Drobak, M. R. Hanley, and A. P. Dawson. 1990. Thapsigargin, a tumor promoter, discharges intracellular $\mathrm{Ca}^{2+}$ stores by specific inhibition of the endoplasmic reticulum $\mathrm{Ca}^{2+}$-ATPase. Proc. Natl. Acad. Sci. USA. 87:2466-2470.

27. Lytton, J., M. Westlin, and M. R. Hanley. 1991. Thapsigargin inhibits the sarcoplasmic or endoplasmic reticulum Ca-ATPase family of calcium pumps. $J$. Biol. Chem. 266:17067-17071.

28. Pfeifle, B., and H. Ditschuneit. 1983. Two separate receptors for insulin and insulin-like growth factors on arterial smooth muscle cells. Exp. Clin. Endocrinol. 81:280-286.

29. Pfeifle, B., and H. Ditschuneit. 1983. Receptors for insulin and insulinlike growth factor in cultured arterial smooth muscle cells depend on their growth state. J. Endocrin. 96:251-257.

30. Bar, R. S., M. Boes, B. L. Dake, B. A. Booth, S. A. Henley, and A. Sandra. 1988. Insulin, insulin-like growth factors, and vascular endothelium. Am. J. Med. 85(Suppl. 5A):59-70.

31. Calviello, G., and M. Chiesi. 1989. Rapid kinetic analysis of the calciumrelease channels of skeletal muscle sarcoplasmic reticulum: the effect of inhibitors. Biochemistry. 28:1301-1306.

32. Oba, T., H. Iwama, and T. Aoki. 1989. Ruthenium red and magnesium ion partially inhibit silver ion-induced release of calcium from sarcoplasmic reticulum of frog skeletal muscles. Jpn. J. Physiol. 39:241-254.

33. Bernhardt, J., M. R. Tschudi, Y. Dohi, I. Gut, B. Urwyler, F. R. Buhler, and T. F. Luscher. 1991. Release of nitric oxide from human vascular smooth muscle cells. Biochem. Biophys. Res. Commun. 180:907-912.

34. Standley, P. R., F. Zhang, J. L. Ram, M. B. Zemel, and J. R. Sowers. 1991. Insulin attenuates vasopressin-induced calcium transients and a voltage-dependent calcium response in rat vascular smooth muscle cells. J. Clin. Invest. 88:1230-1236.

35. Kahn, A. M., R. G. O'Neil, J. C. Allen, C. L. Seidel, and S. S. Navran. 1993. Insulin decreases 5-HT-induced $\mathrm{Ca}^{2+}$ influx, $\mathrm{Ca}^{2+}$ and contraction in vascular smooth muscle cells (VSMCs). FASEB J. 7:A332. (Abstr.)
36. Heyworth, C. M., and M. D. Houslay. 1983. Insulin exerts actions through a distinct species of guanine nucleotide regulatory protein: inhibition of adenylate cyclase. Biochem. J. 214:547-552.

37. McDaniel, N. L., X-L. Chen, H. A. Singer, R. A. Murphy, and C. M. Rembold. 1992. Nitrovasodilators relax arterial smooth muscle by decreasing $[\mathrm{Ca} 2+] \mathrm{i}$ and uncoupling stress from myosin phosphorylation. Am. J. Physiol. 263(Cell Physiol. 32):C461-C467.

38. Pyne, N. J., and M. D. Houslay. 1988. An insulin mediator preparation serves to stimulate the cyclic GMP activated cyclic AMP phosphodiesterase rather than other purified insulin activated cyclic AMP phosphodiesterases. Biochem. Biophys. Res. Commun. 156:290-296.

39. Degerman, E., C. J. Smith, H. Tornqvist, V. Vasta, P. Belfrage, and V. C. Manganiello. 1990. Evidence that insulin and isoprenaline activate the cGMP-inhibited low-Km cAMP phosphodiesterase in rat fat cells by phosphorylation. Proc. Natl. Acad. Sci. USA. 87:533-537.

40. Resink, T. J., V. A. Tkachuck, P. Erne, and F. R. Buhler. 1986. Platelet membrane calmodulin-stimulated calcium-adenosine triphosphatase: altered activity in essential hypertension. Hypertension. 8:159-166.

41. Vincenzi, F. F., C. D. Morris, L. B. Kinsel, M. Kenny, and D. A McCarron. 1986. Decreased calcium pump adenosine triphosphatase in red blood cells of hypertensive subjects. Hypertension. 8:1058-1066.

42. Casteels, R., L. Raeymaekers, G. Droogmans, and F. Wuylack. 1985 $\mathrm{Na}^{+}-\mathrm{K}^{+}$ATPase, Na-Ca exchange, and excitation-contraction coupling in smooth muscle. J. Cardiovasc. Pharmacol. 7(Suppl. 3):S103-S110.

43. Blaustein, M. P. 1988. Sodium/calcium exchange and the control of contractility in cardiac muscle and vascular smooth muscle. J. Cardiovasc. Pharmacol. 12(Suppl. 5):S56-S68

44. Levy, J., J. R. Jr. Gavin, M. R. Hammerman, and L. V. Avioli. 1986. $\mathrm{Ca}^{2+}-\mathrm{Mg}^{2+}$-ATPase activity in kidney basolateral membrane in non-insulin-dependent diabetic rats. Diabetes. 35:899-905.

45. Zemel, M. B., S. Shehin, S. Reddy, W. Lockette, and J. R. Sowers. 1989. Increased vascular reactivity and blood pressure associated with delayed calcium efflux in zucker obese rats. Am. J. Hypertens. 2:30A. (Abstr.)

46. Flatman, J. A., and T. Clausen. 1979. Combined effects of adrenaline and insulin on active electrogenic $\mathrm{Na}^{+}-\mathrm{K}^{+}$transport in rat soleus muscle. Nature (Lond.). 281:580-581.

47. Somlyo, A. V., M. Bond, A. P. Somlyo, and A. Scarpa. 1985. Inositol trisphosphate-induced calcium release and contraction in vascular smooth muscle. Proc. Natl. Acad. Sci. USA. 82:5231-5235.

48. Laakso, M., S. V. Edelman, G. Brechtel, and A. D. Baron. 1990. Decreased effect of insulin to stimulate skeletal muscle blood flow in obese man. $J$. Clin. Invest. 85:1844-1852.

49. Desnuelle, C., V. Askanas, and W. K. Engel. 1987. Insulin enhances development of functional voltage-dependent $\mathrm{Ca}^{2+}$ channels in aneurally cultured human muscle. J. Neurochem. 49:1133-1138.

50. Wu, F., and K. Zierler. 1989. Calcium currents in rat myoballs and their inhibition by insulin. Endocrinology. 125:2563-2572.

51. Clausen, T., and B. R. Martin. 1977. The effect of insulin on the washout of $\left[{ }^{45} \mathrm{Ca}\right]$ calcium from adipocytes and soleus muscle of the rat. Biochem. J. 164:251-255

52. Gupta, M. P., N. Makino, K. Khatter, and N. S. Dhalla. 1986. Stimulation of $\mathrm{Na}^{+}-\mathrm{Ca}^{2+}$ exchange in heart sarcolemma by insulin. Life Sci. 39:1077-1083.

53. Pershadsingh, H. A., and J. M. McDonald. 1979. Direct addition of insulin inhibits a high affinity $\mathrm{Ca}^{2+}$-ATPase in isolated adipocyte plasma membranes. Nature (Lond.). 281:495-497.

54. Draznin, B., M. Kao, and K. E. Sussman. 1987. Insulin and glyburide increase cytosolic free $\mathrm{Ca}^{2+}$ concentrations in isolated rat adipocytes. Diabetes. 36:174-178.

55. Yanagisawa-Miwa, A., H. Ito, and T. Sugimoto. 1990. Effects of insulin on vasoconstriction induced by thromboxane $\mathrm{A}_{2}$ in porcine coronary artery. Circulation. 81:1654-1659.

56. Head, R. J., P. A. Longhurst, R. L. Panek, and R. E. Stitzel. 1987. A contrasting effect of the diabetic state upon the contractile responses of aortic preparations from the rat and rabbit. Br. J. Pharmacol. 91:275-286.

57. Pfaffman, M. A., C. R. Ball, A. Darby, and R. Hilman. 1982. Insulin reversal of diabetes-induced inhibition of vascular contractility in the rat. $\mathrm{Am}$. J. Physiol. 242:H490-H495. 